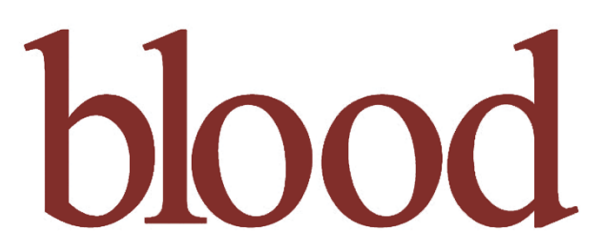

2005 106: 3760-3767

Prepublished online Aug 16, 2005;

doi:10.1182/blood-2005-04-1623

\title{
Induction therapy for adults with acute lymphoblastic leukemia: results of more than 1500 patients from the international ALL trial: MRC UKALL XII/ECOG E2993
}

Jacob M. Rowe, Georgina Buck, Alan K. Burnett, Raj Chopra, Peter H. Wiernik, Susan M. Richards, Hillard M. Lazarus, Ian M. Franklin, Mark R. Litzow, Niculae Ciobanu, H. Grant Prentice, Jill Durrant, Martin S. Tallman, Anthony H. Goldstone and for ECOG and the MRC/NCRI Adult Leukemia Working Party

Updated information and services can be found at:

http://bloodjournal.hematologylibrary.org/cgi/content/full/106/12/3760

Articles on similar topics may be found in the following Blood collections:

Clinical Trials and Observations (2421 articles)

Neoplasia (4117 articles)

Information about reproducing this article in parts or in its entirety may be found online at:

http://bloodjournal.hematologylibrary.org/misc/rights.dtl\#repub_requests

Information about ordering reprints may be found online at:

http://bloodjournal.hematologylibrary.org/misc/rights.dtl\#reprints

Information about subscriptions and ASH membership may be found online at:

http://bloodjournal.hematologylibrary.org/subscriptions/index.dtl

Blood (print ISSN 0006-4971, online ISSN 1528-0020), is published semimonthly by the American Society of Hematology, 1900 M St, NW, Suite 200, Washington DC 20036.

Copyright 2007 by The American Society of Hematology; all rights reserved.

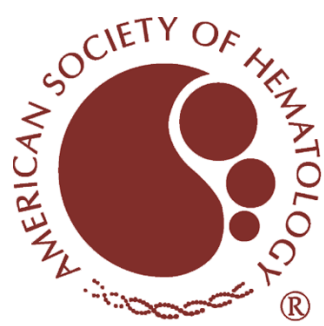




\section{Induction therapy for adults with acute lymphoblastic leukemia: results of more than 1500 patients from the international ALL trial: MRC UKALL XII/ECOG E2993}

Jacob M. Rowe, Georgina Buck, Alan K. Burnett, Raj Chopra, Peter H. Wiernik, Susan M. Richards, Hillard M. Lazarus, Ian M. Franklin, Mark R. Litzow, Niculae Ciobanu, H. Grant Prentice, Jill Durrant, Martin S. Tallman, and Anthony H. Goldstone,

for ECOG and the MRC/NCRI Adult Leukemia Working Party

The international acute lymphoblastic leukemia (ALL) study was designed to prospectively define the optimal therapy for adults 60 years of age or younger with newly diagnosed ALL. All patients received identical induction therapy, and $91 \%$ achieved complete remission (CR). Patients 50 years of age or younger with a compatible sibling were assigned to undergo allogeneic transplantation; the others were randomly assigned to autologous transplantation or to consolidation/maintenance therapy for 2.5 years. Patients who did not achieve CR after induction had an overall survival rate of $5 \%$ compared with $45 \%$ for patients who achieved CR. Factors at diagnosis predictive of overall survival and diseasefree survival were age $(P=.001)$, white blood cell count less than $30 \times 10^{9} / \mathrm{L}$ for $B$ lineage or less than $100 \times 10 \% / L$ for $T$ lineage $(P=.001)$ and immunophenotype, $T$ lineage versus $B$ lineage $(P=.001)$. The data demonstrate that achieving CR with induction therapy is indispensable for long-term survival in adult patients with ALL. Furthermore, with a response rate greater than $90 \%$, the induction regimen was highly efficacious as remissioninducing therapy. This large database has validated several previously identified independent prognostic factors in ALL, such as age, white blood cell count at presentation, cytogenetics, and immunophenotype. However, the achievement of CR within 4 weeks does not appear to be an independent prognostic factor. (Blood. 2005;106:3760-3767)

() 2005 by The American Society of Hematology

\section{Introduction}

In the past 5 decades, the results of treatment for childhood acute lymphoblastic leukemia (ALL) have evolved from a median survival of 2 months from diagnosis ${ }^{1}$ to long-term overall survival rates of approximately $80 \%{ }^{2,3}$ Although the outcome for adults with ALL has certainly improved in the same period, the long-term overall survival rate for adults is only $30 \%$ to $40 \%$ for those younger than 60 years and less than $10 \%$ for those older than 60 years. ${ }^{4-15}$

Historically, several important risk factors have been recognized. One of the most significant prognostic factors has been the response to initial treatment. In many studies, response to initial therapy has been an overriding prognostic factor regardless of the initial disease features. ${ }^{2,5}$ In addition, more recent data suggest that the presence of residual leukemia in the bone marrow on day 7 or 14 has been associated with a worse prognosis, though the published data are predominantly in childhood ALL. ${ }^{16,17}$

Cytogenetic abnormalities are independent prognostic factors in ALL. The most important chromosomal abnormality in ALL is the Philadelphia chromosome $(\mathrm{Ph})$, characterized by the balanced translocation $\mathrm{t}(9 ; 22)(\mathrm{q} 34 ; \mathrm{q} 11)$. Other major cytogenetic abnormalities include $\mathrm{t}(4 ; 11)(\mathrm{q} 21 ; \mathrm{q} 23)$ involving the $M L L$ gene, translocations such as $\mathrm{t}(8 ; 14), \mathrm{t}(1 ; 19)$, and $\mathrm{t}(10 ; 14)$, and structural abnormalities such as $9 \mathrm{p}, 6 \mathrm{q}$, and $12 \mathrm{p} .{ }^{18,19} \mathrm{Ph}$ can also be detected by the polymerase chain reaction for the bcr-abl fusion protein and is present in $20 \%$ to $30 \%$ of adults with ALL. ${ }^{20-22} \mathrm{Ph}$ positivity confers a uniformly poor prognosis with standard chemotherapy.

The initial white blood cell (WBC) count at diagnosis is an important prognostic factor reported in every study of ALL. ${ }^{5,9}$ An arbitrary cutoff of $30 \times 10^{9} \mathrm{WBCs} / \mathrm{L}$ for B-lineage ALL or $100 \times 10^{9} \mathrm{WBCs} / \mathrm{L}$ for T-lineage ALL has often been used in clinical studies. ${ }^{5,14}$

The outcome of therapy for adult ALL is directly dependent on age. Few long-term survivors are older than $60 . .^{7,8}$ Although the relationship between age and prognosis for patients between the ages of 20 and 60 years is a continuum, most clinical studies have chosen an arbitrary age of 30,35 , or 40 years as a cutoff. 5,6,8,23-25

Immunophenotype has traditionally been correlated with prognosis, 5,26,27 though with the advent of molecular diagnostic tools and more intensive therapies this may no longer be an independent prognostic factor. ${ }^{14}$

Finally, sex has been reported to be an independent prognostic factor, with male patients doing less well than female patients, possibly because of the impact of testicular relapse. However, these data have been reported in childhood ALL, ${ }^{28-32}$ and the applicability to adult ALL remains uncertain.
From the Rambam Medical Center and Technion, Israel Institute of Technology, Haifa, Israel; Cancer Trials Support Unit (CTSU), Oxford, United Kingdom; University of Wales, Cardiff, United Kingdom; Christie Hospital National Health Service (NHS) Trust, Manchester, United Kingdom; Our Lady of Mercy Cancer Center, New York Medical College, Bronx, NY; Ireland Cancer Center, University Hospitals of Cleveland, OH; Glasgow Royal Infirmary, Glasgow, United Kingdom; Mayo Clinic College of Medicine, Rochester, MN; Stem Cell Sciences, New York, NY; Royal Free Hospital, London, United Kingdom; Northwestern University Feinberg School of Medicine, Chicago, IL; and University College London (UCL) Hospitals, London, United Kingdom.

Submitted April 21, 2005; accepted July 12, 2005. Prepublished online as Blood First Edition Paper, August 16, 2005; DOI 10.1182/blood-2005-04-1623.
A complete list of the members of the United Kingdom Medical Research Council Adult Leukaemia Working Party and Eastern Cooperative Oncology Group (MRC UKALL XII/ECOG) E2993 Trial appears in "Appendix."

Reprints: Jacob M. Rowe, Department of Hematology and Bone Marrow Transplantation, Rambam Medical Center and Technion, Israel Institute of Technology, Haifa 31096, Israel; e-mail: rowe@jimmy.harvard.edu.

The publication costs of this article were defrayed in part by page charge payment. Therefore, and solely to indicate this fact, this article is hereby marked "advertisement" in accordance with 18 U.S.C. section 1734.

(C) 2005 by The American Society of Hematology 
In 1993 the Medical Research Council (MRC) in the United Kingdom and the Eastern Cooperative Oncology Group (ECOG) in the United States initiated a joint international study, UKALL XII/ECOG 2993, designed to prospectively define the optimal therapy for adult patients with newly diagnosed ALL. The study uses uniform induction therapy and early intensification for all patients, irrespective of their presumed risk groups. The prescribed postremission therapy is intended to evaluate the role of allogeneic and autologous transplantation compared with the more standard protracted consolidation maintenance therapy. More than 1700 patients have already been registered to this trial, and overall outcome data are available on more than 1500 patients, with a median follow-up of 5 years. In this large cohort of patients, the results of induction therapy and an analysis of prognostic factors are reported herein.

\section{Patients, materials, and methods}

The international ALL trial was initiated in 1993 and involves a major transatlantic collaboration between the Medical Research Council (UKALL XII) in the United Kingdom and the Eastern Cooperative Oncology Group (ECOG E2993) in the United States (Figure 1). All patients from 15 to 59 years of age, including $\mathrm{Ph}^{+}$patients, were eligible for this study irrespective of the prognostic factors at presentation. All patients received identical induction therapy, irrespective of risk assessment, including central nervous system (CNS) prophylaxis and treatment of CNS disease, if present at diagnosis. The study was approved by the institutional review board of each treating center for these studies, and informed consent was given according to the Declaration of Helsinki.

\section{Induction therapy}

All patients received phase 1 of induction therapy (weeks 1-4), which consisted of daunorubicin $60 \mathrm{mg} / \mathrm{m}^{2}$ administered intravenously on days $1,8,15$, and 22; vincristine $1.4 \mathrm{mg} / \mathrm{m}^{2}$ administered intravenously on days $1,8,15$, and 22 ; L-asparaginase $10000 \mathrm{IU}$ administered intravenously or intramuscularly on days 17 to 28 and prednisone $60 \mathrm{mg} / \mathrm{m}^{2}$ administered orally in divided doses on days 1 to 28 ; and methotrexate $12.5 \mathrm{mg}$ administered intrathecally on day 15 (Table 1 ). L-asparaginase was initially given at a high dose of $10000 / \mathrm{m}^{2}$ to ECOG patients only from 1993 to 2000. After analysis revealed that there was no difference in efficacy compared with $10000 \mathrm{IU}$ total, ECOG reverted to the lower dose of L-asparaginase.

Patients went on to phase 2 of induction regardless of whether residual leukemia was in their marrow at the end of phase 1. Phase 2 therapy (weeks 5-8) consisted of cyclophosphamide $650 \mathrm{mg} / \mathrm{m}^{2}$ intravenously on days 1 , 15 , and 29 and cytarabine $75 \mathrm{mg} / \mathrm{m}^{2}$ intravenously on days 1 to 4,8 to 11,15 to 18 , and 22 to 25 . 6-Mercaptopurine $\left(60 \mathrm{mg} / \mathrm{m}^{2}\right)$ was administered orally on days 1 to 28 , and methotrexate $12.5 \mathrm{mg}$ was administered intrathecally on days $1,8,15$, and 22 .

MRC UKALL XII / ECOG E2993

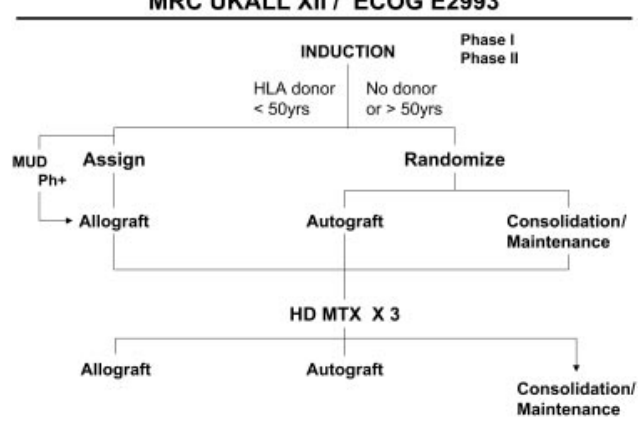

Figure 1. A simplified overall schema of the study. MUD indicates matched unrelated donor transplantation; HD MTX, high-dose methotrexate.
Table 1. Induction therapy: MRC UKALL XII/ECOG E2993

\begin{tabular}{llll}
\hline Phase and therapy & Dosage & $\begin{array}{c}\text { Route of } \\
\text { administration }\end{array}$ & Days administered \\
\hline $\begin{array}{l}\text { Phase 1, weeks 1-4 } \\
\text { Daunorubicin }\end{array}$ & $60 \mathrm{mg} / \mathrm{m}^{2}$ & IV & $1,8,15,22$ \\
$\begin{array}{l}\text { Vincristine } \\
\text { L-asparaginase }\end{array}$ & $1.4 \mathrm{mg} / \mathrm{m}^{2}$ & IV & $1,8,15,22$ \\
$\begin{array}{l}\text { Prednisone } \\
\text { Methotrexate }\end{array}$ & $60 \mathrm{mg} / \mathrm{m}^{2}$ & IV or IM & $17-28$ \\
$\begin{array}{l}\text { Phase 2, weeks 5-8 } \\
\text { Cyclophosphamide }\end{array}$ & $650 \mathrm{mg} / \mathrm{m}^{2}$ & IV & $1-28$ \\
$\begin{array}{l}\text { Cytarabine } \\
\text { 6-Mercaptopurine }\end{array}$ & $75 \mathrm{mg} / \mathrm{m}^{2}$ & IV & $1,15,29$ \\
Methotrexate & $12.5 \mathrm{mg}$ & PO & $1-4,8-11,15-18,22-25$ \\
\hline
\end{tabular}

IV indicates intravenously; IM, intramuscularly; PO, by mouth; IT, intrathecally.

A diagnostic spinal tap was performed on all patients. If CNS leukemia was present at diagnosis, methotrexate administered intrathecally or through an Omaya reservoir was given weekly until the blast cells were no longer present in the spinal fluid. In addition, $2400 \mathrm{cGy}$ cranial irradiation and $1200 \mathrm{cGy}$ to the spinal cord were administered concurrently during phase 2. For such patients with CNS leukemia at presentation, intrathecal methotrexate was not administered during phase 2.

Patients were evaluated for response at the end of each of the 2 phases of induction. Those who achieved complete remission (CR) went on to the intensification and postremission consolidation parts of the study.

After induction therapy all patients younger than 50 years of age who had a human leukocyte antigen (HLA)-compatible sibling were assigned to undergo allogeneic transplantation. All other patients were randomly assigned between autologous transplantation and standard consolidation/maintenance therapy. Patients who were $\mathrm{Ph}^{+}$were offered a search for a matched unrelated donor if they did not have a histocompatible family donor.

\section{Intensification therapy}

After this assignment or randomization, all patients received intensification therapy with 3 cycles of high-dose methotrexate, $3 \mathrm{~g} / \mathrm{m}^{2}$ intravenously given on days 1,8 , and 22, followed by L-asparaginase $10000 \mathrm{IU}$ on days 2, 9 , and 23 and standard leucovorin rescue. After this intensification, patients went on to receive their previously assigned or randomized therapy.

\section{Transplantation regimen}

The conditioning regimen for patients undergoing allogeneic and autologous transplantation was identical, consisting of total body irradiation (TBI) for a total dose of $1320 \mathrm{cGy}$, given twice daily in 6 fractions of $220 \mathrm{cGy}$ on days -6 to -4 , followed by etoposide $60 \mathrm{mg} / \mathrm{kg}$ intravenously on day -3 .

No posttransplantation therapy was specified for patients undergoing allogeneic or autologous transplantation. The exception was for $\mathrm{Ph}^{+}$ patients, for whom $3 \times 10^{6} \mathrm{U} \alpha$-interferon was given 3 times a week for 15 months.

\section{Consolidation/maintenance therapy}

Patients randomly assigned to consolidation/maintenance therapy received CNS prophylaxis if leukemia was not present at diagnosis. Intrathecal cytarabine, $50 \mathrm{mg}$, was given weekly for 4 weeks, together with $2400 \mathrm{cGy}$ cranial irradiation. In addition, $50 \mathrm{mg}$ intrathecal cytarabine was given on 4 occasions 3 months apart during maintenance therapy.

This nontransplantation postremission therapy included 4 cycles of consolidation therapy followed by maintenance therapy. Cycle 1 of consolidation therapy consisted of cytarabine $75 \mathrm{mg} / \mathrm{m}^{2}$ intravenously on days 1 to 5 ; etoposide $100 \mathrm{mg} / \mathrm{m}^{2}$ intravenously on days 1 to 5 ; vincristine $1.4 \mathrm{mg} / \mathrm{m}^{2}$ intravenously on days $1,8,15$, and 22 ; and dexamethasone 10 $\mathrm{mg} / \mathrm{m}^{2}$ orally on days 1 to 28 .

Cycle 2 was started 4 weeks after cycle 1 and consisted of cytarabine 75 $\mathrm{mg} / \mathrm{m}^{2}$ intravenously on days 1 to 5 and etoposide $100 \mathrm{mg} / \mathrm{m}^{2}$ intravenously on days 1 to 5 . 
Cycle 3 was started 4 weeks after cycle 2 . It consisted of daunorubicin $25 \mathrm{mg} / \mathrm{m}^{2}$ intravenously on days $1,8,15$, and 22 , cyclophosphamide 650 $\mathrm{mg} / \mathrm{m}^{2}$ intravenously on day 29 , cytarabine $75 \mathrm{mg} / \mathrm{m}^{2}$ intravenously on days 31 to 34 and 38 to 41 , and thioguanine $60 \mathrm{mg} / \mathrm{m}^{2}$ orally on days 29 to 42 .

Cycle 4 of consolidation therapy was identical to cycle 2 and was to begin 8 weeks after the conclusion of cycle 3 .

Maintenance therapy consisted of vincristine $1.4 \mathrm{mg} / \mathrm{m}^{2}$ intravenously every 3 months, prednisone $60 \mathrm{mg} / \mathrm{m}^{2}$ orally for 5 days every 3 months, 6-mercaptopurine $75 \mathrm{mg} / \mathrm{m}^{2}$ orally each day, and methotrexate $20 \mathrm{mg} / \mathrm{m}^{2}$ orally or intravenously once a week. Maintenance therapy was to continue for a total of 2.5 years from the start of intensification therapy.

Table 2 outlines the prognostic risk factors used in this study for analyses of the results for $\mathrm{Ph}^{-}$patients. $\mathrm{Ph}^{+}$patients were considered the highest risk group, and their therapy included the option of matched unrelated donor transplantation (Figure 1). Patients who were $\mathrm{Ph}^{-}$were considered at high risk if any of the following were present: age 35 years and older; time to CR more than 4 weeks or WBC count more than $30 \times 10^{9} / \mathrm{L}$ for B-lineage ALL and more than $100 \times 10^{9} / \mathrm{L}$ for T-lineage $\mathrm{ALL}$. $\mathrm{Ph}^{-}$patients who had none of these risk factors were considered at standard risk.

\section{Statistical analysis}

The main analyses are of survival and of disease-free survival defined as time to death or to relapse or death, respectively. Actuarial event percentages were calculated by the Kaplan-Meier method. ${ }^{33}$ For patients without an event, observation was censored at the last contact date. The log rank method was used for initial univariate comparisons between groups. Multivariate analysis was performed by logistic regression (for CR) or by Cox regression (for survival and event-free survival) using the SAS statistical package (SAS Institute, Cary, NC).

Prognostic variables examined were $\mathrm{Ph}$ status, age, sex, WBC count, immunophenotype, and time to first remission. All were treated as categorical variables for most analyses, but additional multivariate analyses were performed with age and WBC count as continuous variables. The purpose was not to define new prognostic variables but to verify known ones and to suggest groups that might be used in the future for subgroup treatment comparisons, particularly when the balance of risk and benefit might change over subgroups, such as transplantation versus chemotherapy.

\section{Results}

As of December 31, 2004, a total of 1713 patients were registered to the study; however, the results presented include only mature data that were available as of October 2003 for 1521 patients who had completed induction therapy and for whom remission status was known.

\section{Induction}

Table 3 summarizes the overall results from induction therapy. The CR was $91 \%$ for all 1521 patients, $93 \%$ for the $1153 \mathrm{Ph}^{-}$patients, and $83 \%$ for the $293 \mathrm{Ph}^{+}$patients. The CR rate was $97 \%$ for the 533 $\mathrm{Ph}^{-}$patients at standard risk (based only on age and WBC count at diagnosis), and it was $90 \%$ for the $590 \mathrm{Ph}^{-}$patients at high risk. At the time of collection of data for this report, the $\mathrm{Ph}$ status was unknown for $75(5 \%)$ patients.

Table 2. Risk factors for Ph- ALL: MRC UKALL XII/ECOG E2993

\begin{tabular}{lc}
\hline High risk (any of the following) & Standard risk (all of the following) \\
\hline More than 35 years old & Less than 35 years old \\
More than 4 weeks to CR & Less than 4 weeks to $C R$ \\
WBC count above $30 \times 10^{9} / \mathrm{L}$ & WBC count below $30 \times 10^{9} / \mathrm{L}$ \\
(B lineage) & (B lineage) \\
WBC count above $100 \times 10^{9} / \mathrm{L}$ & WBC count below $100 \times 10^{9} / \mathrm{L}$ \\
(T lineage) & (T lineage)
\end{tabular}

Table 3. Results of induction therapy

\begin{tabular}{lrccc}
\hline & No. & CR, \% & 5-y survival, \% & $\begin{array}{c}\text { 5-y survival for } \\
\text { patients in CR, \% }\end{array}$ \\
\hline All patients & 1521 & 91 & 38 & 41 \\
$\mathrm{Ph}^{+}$ & 293 & 83 & 25 & 28 \\
Ph $^{-}$ & 1153 & 93 & 41 & 44 \\
Standard risk* $^{*}$ & 533 & 97 & 54 & 57 \\
High risk $^{*}$ & 590 & 90 & 29 & 35 \\
Unknown risk & 30 & 84 & 23 & 28 \\
\hline
\end{tabular}

${ }^{\star}$ Risk stratification at diagnosis based on age and WBC count only.

\section{Overall survival}

Overall survival rates at 5 years in this study were $38 \%$ for all patients, $41 \%$ for $\mathrm{Ph}^{-}$patients, and $25 \%$ for $\mathrm{Ph}^{+}$patients (Figure 2).

Figure 3 depicts overall survival for the 22 patients who did not achieve CR in this study (ie, after 2 phases of induction therapy). The rate for this small group was only $5 \%$ compared with $45 \%$ for $\mathrm{Ph}^{-}$patients who achieved CR.

\section{Toxicity}

Overall mortality rates for induction therapy, defined as from the time of registration for the study, were $4.7 \%$ (54 of 1153 patients) for $\mathrm{Ph}^{-}$patients and 5.5\% (16 of 293 patients) for $\mathrm{Ph}^{+}$patients. Twenty-nine patients died of infection, most significantly Aspergillus ( 7 patients). Five patients died of hemorrhage ( 3 pulmonary, 2 cerebral), 2 patients died of thromboses (possibly related to L-asparaginase), and 1 patient died from tumor lysis. The remaining 10 patients died of causes described as multiorgan failure, which might also have been related to an infectious etiology.

\section{Prognostic factors}

Figure 4 demonstrates the overall superiority among $\mathrm{Ph}^{-}$patients at standard risk compared with those at high risk. The differences are significant when measured either from time of diagnosis or from the point at which complete remission was achieved.

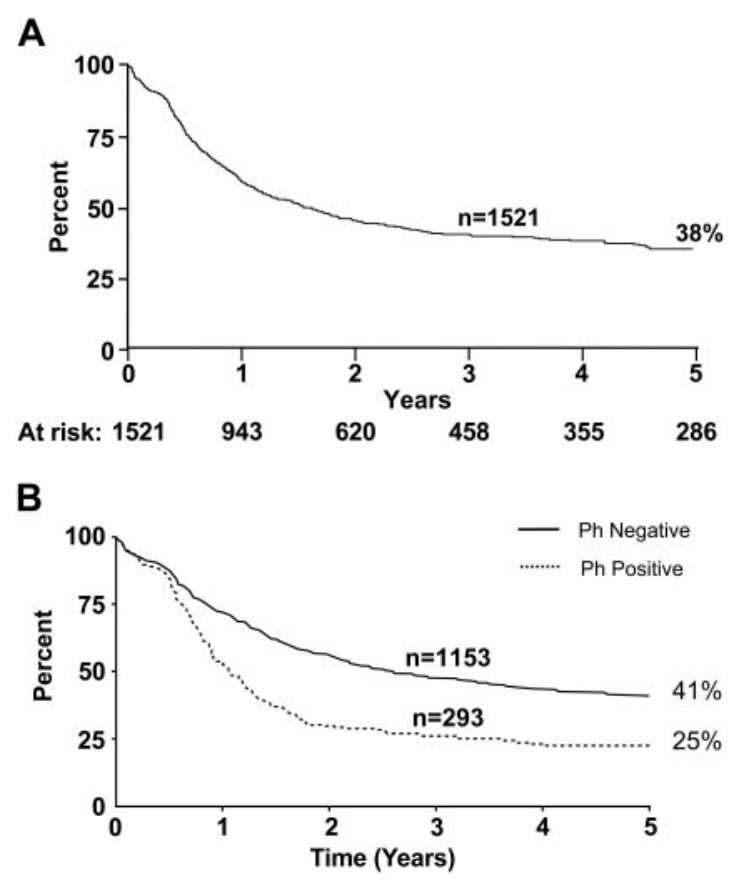

Figure 2. Overall survival for all patients. (A) This study. (B) Ph status. 


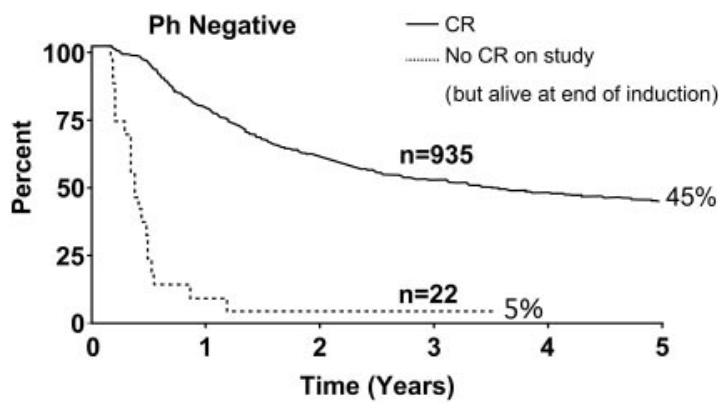

Figure 3. Overall survival for all patients in CR and for the 22 patients who did not achieve $C R$ at the end of induction therapy.

Seven hundred seventy-eight patients achieved CR during the 4 weeks of phase 1 of induction therapy. The 5-year survival rate for this group was $46 \%$. For the 157 patients who required more than one cycle of induction therapy to achieve CR (ie, more than 4 weeks), the 5-year survival rate was $41 \%$ (Figure 5). This difference was not significant by univariate or multivariate analysis.

Figure 6 illustrates overall survival for $\mathrm{Ph}^{-}$patients by age. Survival decreased with increasing age; age 35 years was a significant cutoff point $(P<.001)$. Figure 7 illustrates overall survival by immunophenotype; the T-lineage group had a significant though slight advantage compared with the B-lineage group $(P=.001)$. Tables 4 and 5 summarize the overall risk factors that were significant by multivariate analyses for $\mathrm{Ph}^{-}$patients, either for CR (Table 4) or for overall survival and disease-free survival (Table 5). For the achievement of CR, age (35 years or older) and sex were the only significant factors. For overall survival and disease-free survival, age (35 years or older), WBC count at presentation $\left(30 \times 10^{9} / \mathrm{L}\right.$ for B-lineage ALL and $100 \times 10^{9} / \mathrm{L}$ for T-lineage) and immunophenotype were significant risk factors. Table 6 summarizes the results of multivariate logistic or Cox regression analysis, with age and $\mathrm{WBC}$ count as continuous variables.
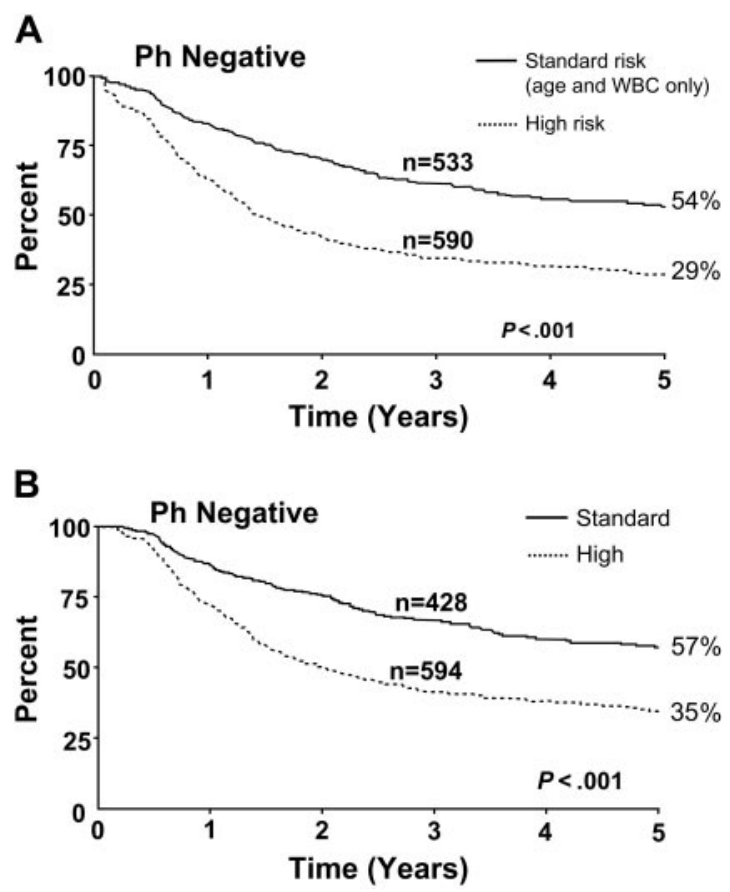

Figure 4. Patients at standard risk had better overall survival rates from the time of diagnosis. This included (A) all patients and (B) patients who achieved CR.

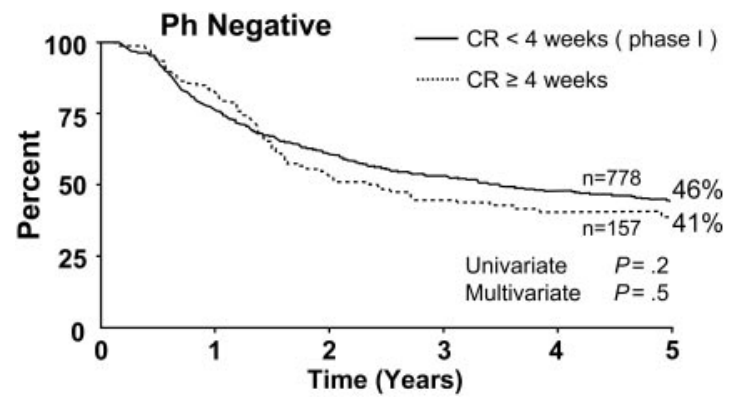

Figure 5. Overall survival by time to achieve CR.

Time to achievement of CR was not an independently significant risk factor. Analysis of the data by censoring at transplantation, performed at any time, made little difference in the effects of age and WBC count. More important, it did not affect the lack of independent significance of time to achievement of CR.

Table 7 summarizes the overall prognostic factors in this study. The group with the best prognosis was the $\mathrm{Ph}^{-}$group at low risk, for whom the long-term overall survival rate was $55 \% . \mathrm{Ph}^{-}$ patients who had one adverse risk factor (age older than 35 years or high WBC count) had an overall survival rate of $34 \%$. On the other hand, $\mathrm{Ph}^{-}$patients who were older than 35 years and had a WBC count greater than $100 \times 10^{9} / \mathrm{L}$ at presentation were considered to be at very high risk; their overall survival rate was only $5 \%$, worse than that of the $\mathrm{Ph}^{+}$group as a whole.

\section{Discussion}

In this report no attempt is made to analyze postremission therapies because the study is ongoing. Data are based solely on the results of induction therapy, irrespective of the postremission therapy assignment or randomization. Given the large database, the aim of the report was to examine long-established prognostic factors and to determine whether they could be validated in this ongoing trial. Furthermore, the results of induction therapy in this transatlantic study, involving more than 100 participating centers, have been described.

This report has focused on results for $\mathrm{Ph}^{-}$patients; reference to $\mathrm{Ph}^{+}$patients was made only for comparative purposes. The study itself has already been closed for $\mathrm{Ph}^{+}$patients, and the preliminary details of this have been reported. ${ }^{34}$

The CR rate of $93 \%$ for $\mathrm{Ph}^{-}$patients was certainly at least as good as anything that has been published for this patient population. However, caution is necessary in interpreting long-term outcomes based on CR rate because overall survival and diseasefree survival may be influenced to the same or to a greater degree

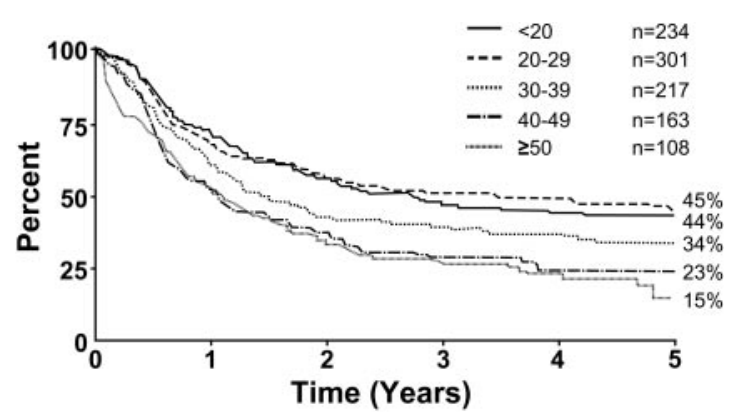

Figure 6. Overall survival by age. 


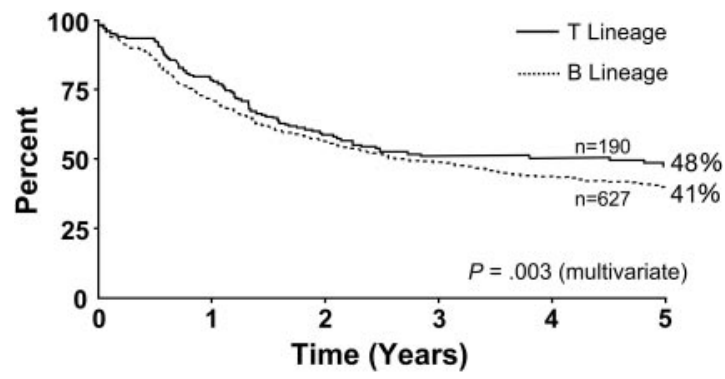

Figure 7. Overall survival by immunophenotype.

by type and intensity of postremission therapy. Nevertheless, this high response rate confirms the efficacy of the induction regimen, with its relatively low toxicity, allowing for a very high percentage of patients to receive postremission therapy. Patients who did not achieve CR at the end of induction therapy fared poorly (Figure 3), demonstrating that $\mathrm{CR}$ is critical with induction therapy if there is to be any realistic hope of survival.

This study confirmed the importance of age as a prognostic factor for adult ALL and is consistent with findings in previous studies of ALL. $2,5,6,8-10,13,14,23-25,35,36$

Achievement of CR within 4 weeks of therapy has been a time-honored prognostic factor for adult patients with ALL. ${ }^{2,5}$ However, it could not be confirmed as an independent prognostic factor in this study despite careful univariate and multivariate analyses. Although this result may appear surprising at first, it must be remembered that the 4-week cutoff is an arbitrary one and does not preclude the notion that an early response to therapy confers a better prognosis. Recent reports in childhood ALL have suggested that a response within 7 to 14 days is associated with the best prognosis ${ }^{16-18}$; however, this has never been prospectively confirmed in adult ALL, although some therapeutic strategies in the most recent protocols have attempted to use very early response as a prognostic factor for risk-adapted therapy.

It is clearly recognized that prognostic factors are dependent on postremission therapy no less than on induction therapy. In contrast to most previous studies, this trial included transplantation as a major postremission modality. In theory, this might have blunted the importance of certain classic prognostic factors, especially time to CR. However, analysis of the data-censoring at transplantation performed at any time- - did not materially alter the significance of the prognostic factors or, more important, the lack of significance of time to CR.

The data clearly indicate the superiority of outcomes of $\mathrm{Ph}^{-}$ patients over the outcomes of those with the $\mathrm{Ph}^{+}$abnormality. Although other cytogenetic features clearly have prognostic significance-especially $\mathrm{t}(4 ; 11), \mathrm{t}(8 ; 14), \mathrm{t}(1 ; 19)$, and $\mathrm{t}(10 ; 14)$ and structural abnormalities such as $9 \mathrm{p}, 6 \mathrm{q},-7$ or +8 , and $12 \mathrm{p}^{19,20}$ - these factors were not prospectively written into this study when it was

Table 4. Risk factors shown to be significant for complete remission: MRC UKALL XII/ECOG E2993

\begin{tabular}{lcc}
\hline & $\begin{array}{c}\text { Patients in CR/ } \\
\text { total no. (\%) }\end{array}$ & $\boldsymbol{P}$ \\
\hline $\begin{array}{l}\text { Age } \\
\text { Younger than } 35 y\end{array}$ & $630 / 651(96)$ & \\
$\begin{array}{l}35 \text { y and older } \\
\text { Sex } \\
\text { Male }\end{array}$ & $305 / 344(89)$ & .001 \\
Female & $587 / 619(95)$ & \\
\hline
\end{tabular}

Risk factors as assessed by multivariate analysis for $\mathrm{Ph}^{-}$patients.
Table 5. Risk factors shown to be significant for overall and disease-free survival

\begin{tabular}{lr}
\hline & \multicolumn{1}{c}{$\boldsymbol{P}$} \\
\hline Age: 35 y and older vs younger than $35 \mathrm{y}$ & $<.001$ \\
WBC count: $30 \times 10^{9} / \mathrm{L}$ B lineage or $100 \times 10^{9} / \mathrm{L}$ T lineage & $<.001$ \\
T lineage vs B lineage & .001 \\
\hline
\end{tabular}

designed in the early 1990s. This analysis has, therefore, been limited to the $\mathrm{Ph}^{-}$group as a whole. Cytogenetic analysis, however, is a mandatory part of the study, and the data will be collected and reported at study end.

Sex was an independent predictive factor for CR, though not for overall survival or disease-free survival. Surprisingly, men did better than women, which is in contrast to published data in childhood ALL. ${ }^{28-32}$ It is not known whether this is related to a higher incidence of testicular relapse in childhood ALL or is associated with a higher frequency of T-ALL in children. Furthermore, in one study of adult ALL, men had inferior outcomes. ${ }^{24}$

Immunophenotyping has long been considered a critical part of the diagnostic evaluation of patients with ALL. ${ }^{26,32}$ Until recently, the prognostic usefulness of immunologic classification has been reproduced in virtually every study. Although detailed immunophenotypic analysis of patients will be performed at the closure of this trial, data available at this time permit only limited comparison of overall $\mathrm{T}$ lineage with $\mathrm{B}$ lineage. The limitation of this is recognized, and a more complete analysis of the immunophenotype at various stages of maturation will ultimately provide more accurate prognostic information. Cytogenetic and molecular classification may, in the future, supersede immunophenotyping as a critical diagnostic tool. In a recent report, immunophenotyping was not an independently significant prognostic factor. ${ }^{14}$

Looking at the overall prognosis among all groups of patients, it was noted that $\mathrm{Ph}^{-}$patients who were older than 35 years and had WBC counts greater than $30 \times 10^{9} / \mathrm{L}$ for B lineage or greater than $100 \times 10^{9} / \mathrm{L}$ for $\mathrm{T}$ lineage had extremely poor prognoses that were even worse than those of the $\mathrm{Ph}^{+}$group as a whole (Table 7). This, of course, has not been compared with the $\mathrm{Ph}^{+}$patients who have similar features. These data, however, suggest that alternative therapies should be considered for this group. It is likely that allogeneic transplantions from alternative donors will also be incorporated in future trials for these patients at very high risk.

Newer therapies are continually being proposed for adult patients with ALL, and some recent data suggest that intensifying the early phases of therapy may have an impact on survival.9,13,37,38 Such advances, if they are confirmed in large prospective studies, will further refine the prognostic information and the selection of

Table 6. Multivariate logistic or Cox regression analysis with age and WBC count as continuous variables

\begin{tabular}{lrr}
\hline Status and risk factors & Odds ratio/hazard ratio & $\boldsymbol{P}$ \\
\hline Complete remission & & $<.001$ \\
Age & 0.949 & .048 \\
Sex & 0.631 & \\
Overall survival & & $<.001$ \\
Age & 1.027 & $<.001$ \\
WBC count & 1.002 & .018 \\
B or T lineage & 0.770 & \\
Disease-free survival & & $<.001$ \\
Age & 1.021 & $<.001$ \\
WBC count & 1.002 & .005 \\
B or T lineage & 0.738 & \\
\hline
\end{tabular}


Table 7. Overall prognostic groups: MRC UKALL XII/ECOG E2993 prognostic factors

\begin{tabular}{|c|c|}
\hline Risk level & Prognostic factors \\
\hline \multicolumn{2}{|l|}{ Low risk } \\
\hline $\mathrm{Ph}^{-}$ & $\begin{array}{l}\text { Under age } 35 \text { years AND a WBC count below } \\
100 \times 10 \% \text { ( } \mathrm{T} \text { lineage) or } 30 \times 10^{9} / \mathrm{L} \text { ( } \mathrm{B} \text { lineage }\end{array}$ \\
\hline \multicolumn{2}{|c|}{ Intermediate risk } \\
\hline $\mathrm{Ph}^{-}$ & $\begin{array}{l}\text { Under age } 35 \text { years AND a WBC count above } \\
100 \times 10^{9} / \mathrm{L} \text { ( } \mathrm{T} \text { lineage) or } 30 \times 10^{9} / \mathrm{L} \text { (B lineage }\end{array}$ \\
\hline & OR \\
\hline $\mathrm{Ph}^{+}$ & $\begin{array}{l}\text { Age } 35 \text { years or older AND a WBC count below } \\
100 \times 10^{9} / \mathrm{L}\left(\mathrm{T} \text { lineage) or } 30 \times 10^{9} / \mathrm{L} \text { ( } \mathrm{B} \text { lineage }\right.\end{array}$ \\
\hline \multicolumn{2}{|l|}{ High risk } \\
\hline $\mathrm{Ph}^{-}$ & $\begin{array}{l}\text { Over age } 35 \text { years AND a WBC count above } \\
100 \times 10^{9} / \mathrm{L}\left(\mathrm{T} \text { lineage) or } 30 \times 10^{9} / \mathrm{L} \text { ( } \mathrm{B} \text { lineage }\right.\end{array}$ \\
\hline
\end{tabular}

appropriate therapies for adults. Furthermore, molecular information, including studies of minimal residual disease at early time points ${ }^{39}$ and advances in genomics, are likely to further define the best prognostic factors in ALL. Until these newer modalities have been confirmed in prospective studies, the more traditional prognostic factors continue to guide current therapy of adult ALL.

Other current studies also question whether specific age groups may benefit from more intensified treatment regimens. ${ }^{40-42}$ These approaches, if confirmed in prospective studies, may also have an impact on the future therapy of ALL.

In summary, the data described in this study have reported on one of the largest studies ever conducted in adult ALL based on data from multiple institutions in 2 large cooperative groups on both sides of the Atlantic. The overall CR rate exceeding $90 \%$ in this study (93\% for $\mathrm{Ph}^{-}$patients) is higher than that previously reported in large studies. Defining the prognostic factors described in this study may have particular relevance, especially in light of the fact that of all the current large studies, this prospective trial includes more intensive postremission therapies (allogeneic or autologous transplantation) than others. Furthermore, every single patient (apart from the $\mathrm{Ph}^{+}$patients) received identical therapy throughout induction and postremission therapy, irrespective of their risk groups. Finally, in contrast to previously published data, time to CR could not be demonstrated in this study to be an independently significant prognostic factor.

\section{Appendix}

Participants in this study included the following people:

\section{MRC UKALL XII doctors}

United Kingdom. Dr J. E. Chandler, Dr D. Plews, and Dr A. C. Wood, James Cook University Hospital; Dr A. Cuthbert, Airedale General Hospital; Dr L. J. Newton, Dr L. A. Parapia, and Dr A. T. Williams, Bradford Royal Infirmary; Dr K. R. Speed, Diana Princess of Wales Hospital; Dr C. Carter, Huddersfield Royal Infirmary; Dr Sahra Ali, Dr R. D. Patmore, and Dr M. L. Shields, Hull Royal Infirmary; Dr S. M. Rajah, Seacroft Hospital; Prof J. A. Child, Dr P. Hillmen, Prof G. J. Morgan, Dr D. R. Norfolk, and Dr G. M. Smith, Leeds General Infirmary; Dr M. C. Galvin and Dr P. Hillmen, Pinderfields General Hospital; Dr D. L. Barnard, Dr S. E. Kinsey, and Dr B. A. McVerry, St. James's University Hospital; Dr L. R. Bond and Dr M. R. Howard, York Hospital; Dr A. J. Steed, Halifax General Hospital; Dr D. Wright, Pontefract General Infirmary; Dr Jim Cavet, Dr R. Chopra, and Dr Mike Dennis, Christie Hospital; Dr P. Carrington, Dr M. Garg, and Dr J. B. Houghton, Salford Royal Hospitals
NHS Trust; Dr J. Burthem, Prof J. A. Liu Yin, and Dr G. S. Lucas, Manchester Royal Infirmary; Dr P. R. Kelsey, Victoria Hospital; Dr J. V. Clough and Dr E. Rhodes, Countess of Chester Hospital; Prof J. C. Cawley, Dr P. Chu, Prof R. E. Clark, and Dr A. R. Pettitt, Royal Liverpool University Hospital; Dr P. A. Stevenson, Walton Hospital; Dr G. Satchi and Dr J. Tappin, Whiston Hospital; Dr N. Butt, Dr T. J. Deeble, Dr D. W. Galvani, Arrowe Park Hospital; Dr Ranjit Dasgupta, Dr A. Olujohungbe, Dr W. Sadik, Dr B. E. Woodcock, University Hospital Aintree; Dr A. McKernan and Dr D. C. Mitchell, Derbyshire Royal Infirmary; Dr M. Auger and Dr E. C. L. Logan, King's Mill Hospital; Dr C. S. Chapman, Dr C. Haworth, Dr A. E. Hunter, Dr R. M. Hutchinson, and Dr J. K. Wood, Leicester Royal Infirmary; Dr M. A. Adelman, Dr D. R. Prangnell and Dr Cathy Williams, Lincoln County Hospital; Dr J. L. Byrne, Dr A. P. Haynes, Dr P. A. E. Jones, Dr A. McMillan, and Prof N. H. Russell, Nottingham City Hospital; Dr J. M. Davies and Dr G. Dolan, Nottingham University Hospital; Dr S. Sobolewski and Dr V. M. Tringham, Pilgrim Hospital; Dr D. C. Rees, Dr J. A. Snowden, Dr E. Vandenberghe, and Dr D. A. Winfield, Royal Hallamshire Hospital; Dr B. Paul, Bassetlaw Hospital; Dr H. F. Barker and Dr P. C. Taylor, Rotherham District General; Dr D. Chandra, Dr R. C. Chasty, Dr P. M. Chipping, and Dr R. M. Ibbotson, North Staffs Hospital Centre; Dr Oliver Chapman, Dr R. I. Harris, Dr Beth Harrison, Dr N. Jackson, Dr Juliet Mills, and Dr M. J. Strevens, University Hospitals Coventry \& Walsgrave; Dr D. Bareford, Sandwell \& West Birmingham Hospital; Dr C. Fegan, Dr M. J. Leyland, and Dr D. W. Milligan, Birmingham Heartlands Hospital; Dr M. Narayanan, George Eliot Hospital; Dr M. S. Hamilton, Dr S. M. Jobanputra, and Dr J. Tucker, Good Hope Hospital NHS Trust; Dr G. P. Galvin, Manor Hospital; Dr S. Basu, Dr S. I. Handa, Dr A. MacWhannell, and Dr A. M. Patel, The Royal Wolverhampton Hospital; Dr B. J. Boughton, Dr J. A. Holmes, Dr P. Mahendra, Dr J. A. Murray, Queen Elizabeth Hospital, Birmingham; Dr S. I. Handa and Dr P. J. Stableforth, Sandwell \& West Birmingham Hospital; Dr J. A. Murray, Selly Oak Hospital; Dr T. A. S. Amos, Dr T. A. J. Phaure, and Dr P. Revell, Staffordshire General Hospital; Dr S. Basu and Dr P. E. Rose, University Hospitals Coventry; Dr N. Pemberton, Dr S. Shafeek, and Dr R. Stockley, Worcestershire Royal Hospital; Dr L. G. Robinson, Hereford County Hospital; Dr J. Neilson, Dr S. G. N. Richardson, and Dr Craig Taylor, Russells Hall Hospital; Dr J. I. O. Craig, Prof A. R. Green, and Dr R. Marcus, Addenbrooke's NHS Trust; Dr N. J. Dodd, Ipswich Hospital; Dr H. M. Daly and Dr T. R. Mitchell, James Paget Hospital; Dr A. M. Deane, Dr J. Leslie, Dr J. Parker, Dr G. E. Turner, and Dr J. Z. Wimperis, Norfolk \& Norwich University Hospital N; Dr J. Z. Wimperis, Peterborough District Hospital; Dr P. Coates and Dr J. Keidan, Queen Elizabeth Hospital, King's Lynn; Dr P. Harper, West Suffolk Hospital; Dr I. J. Durrant, The Horton Hospital; Dr C. Bunch, Dr P. Emerson, Dr C. Hatton, and Dr T. J. Littlewood, Oxford Radcliffe Hospitals, The John Radcliffe Hospital; Dr D. J. Moir and Dr D. M. White, Milton Keynes General NHS Trust; Dr M. E. Haines, Dr J. R. Y. Ross, and Dr S. S. Swart, Northampton General Hospital; Dr F. Booth, Dr H. Grech, and Dr G. Morgenstern, Royal Berkshire Hospital; Dr A. M. O'Hea, Dr S. M. Sheerin, and Dr A. Watson, Stoke Mandeville Hospital; Dr R. Aitchison, Dr S. Kelly, and Dr J. K. Pattinson, Wycombe General Hospital; Dr D. L. Aston, Dr A. E. Milne, and Dr T. J. C. Nokes, The North Hampshire Hospital; Dr A. J. Bell and Dr F. Jack, Poole Hospital NHS Trust; Dr M. Ganczakowski, Queen Alexandra Hospital; Dr C. J. C. Knechtli, Dr C. R. J. Singer, and Prof J. G. Smith, Royal United Hospital NHS Trust, Bath; Dr A. J. Bell, Dr Rachel Hall, Prof T. J. Hamblin, Dr Sally Killick, and Dr H. Myint, Royal Bournemouth Hospital; Dr J. O. Cullis, Salisbury District Hospital; Dr A. Duncombe, Dr A. Duncombe, Dr J. Kohler, Dr K. Orchard, Dr D. Richardson, and Dr A. G. Smith, Southampton University Hospital Trust; Dr A. H. Moosa, Dorset County Hospital; Dr G. L. Scott, Bristol Royal Infirmary; Dr E. Blundell, Dr R. Lush, and Dr J. Ropner, Cheltenham General Hospital; Dr J. A. Copplestone, Dr M. D. Hamon, Dr A. Prentice, and Dr S. A. J. Rule, Derriford Hospital; Dr J. Ropner, Gloucestershire Royal Hospital; Dr B. Attock, North Devon District Hospital; Dr J. Blundell, Dr M. D. Creagh, Dr A. R. Kruger, and Dr R. Noble, Royal Cornwall Hospital (Treliske); Dr M. V. Joyner, Dr R. Lee, and Dr C. E. Rudin, Royal Devon and Exeter Hospital; Dr R. S. Evely and Prof J. Hows, Southmead Hospital; Dr S. 
Bolam, Dr S. V. Davies, Dr S. A. N. Johnson, and Dr S. Rule, Taunton \& Somerset NHS Trust; Dr S. R. Smith and Dr D. L. Turner, Torbay Hospital; Dr J. M. Bird, Dr R. Evely, Prof J. Hows, and Dr D. Marks, Bristol Haematology and Oncolog; Dr A. Virchis, Barnet General Hospital; Dr K. Ryan, Central Middlesex Hospital; Dr M. Foadi, Charing Cross Hospital; Dr G. Abrahamson, Dr U. M. Hegde, and Dr N. J. Philpott, Ealing Hospital; Dr D. Harvey Edgware, General Hospital, Middlesex; Prof J. M. Goldman and Dr E. Kanfer, Hammersmith Hospital, Imperial College London; Dr R. Jan-Mohamed and Dr R. Kaczmarski, Hillingdon Hospital; Dr S. Allard, Dr T. J. Corbett, Dr N. Panoskaltsis, Dr C. D. L. Reid, and Dr P. Skacel, Northwick Park Hospital; Dr S. H. Abdalla, St. Mary's Hospital, London; Dr R. G. Hughes, West Middlesex University Hospital; Dr A. McMillan, Mount Vernon Hospital; Dr J. F. M. Harrison, Hemel Hempstead General Hospital; Dr J. VanDePette, Frimley Park Hospital NHS Trust; Dr C. Dearden and Dr Mark Ethell, Royal Marsden Hospital; Dr P. C. Bevan and Dr S. L. Janes, St. Richard's Hospital; Dr D. H. Bevan, Dr C. E. Dearden, Dr J. C. W. Marsh, Dr Marie Scully, and Dr Fenella Willis, St. George's Hospital NHS Trust; Dr J. Mercieca, St. Helier Hospital; Dr F. Matthey, East Surrey Hospital; Dr A. S. Laurie, Ashford \& St. Peter's Hospital; Dr A. M. O'Driscoll, Dr C. L. Rist, and Dr A. W. W. Roques, Worthing Hospital; Dr I. D. C. Douglas and Dr G. Robbins, Royal Surrey County Hospital; Dr M. Treacy, Chase Farm Hospital; Dr J. K. Luckit, North Middlesex Hospital; Prof A. V. Hoffbrand, Dr A. B. Mehta, Dr M. N. Potter, Prof H. G. Prentice, Royal Free Hospital, London; Dr A. Eden, Southend General Hospital; Prof T. A. Lister and Prof A. Z. S. Rohatiner, St. Bartholomew's Hospital; Dr K. Ardeshna, Dr S. Devereux, Prof A. H. Goldstone, Dr A. Khwaja, Prof D. C. Linch, Dr A. Nathwani, Dr K. G. Patterson, Dr J. B. Porter, and Dr K. Yong, University College Hospital, London; Dr C. C. Anderson and Dr C. DeSilva, Whipps Cross Hospital; Dr N. Akhtar, King George Hospital; Dr R. M. Ireland, Queen Elizabeth Hospital, London; Dr P. A. Gover and Dr R. J. Grace, Eastbourne District General; Dr C. F. M. De Lord, The Princess Royal University Hospital; Dr R. Carr, Dr C. C. Ozanne, and Dr S. A. Schey, Guy's Hospital; Dr K. Saied, Thanet Healthcare NHS Trust, Queen Elizabeth the Queen Mother Hospital; Dr C. F. E. Pocock, Kent \& Canterbury Hospital; Prof G. Mufti, King's College Hospital; Dr M. L. Tillyer, University Hospital Lewisham; Dr D. S. Gillett and Dr C. Taylor, Pembury Hospital; Dr S. Bowcock, Dr S. Rassam, and Dr S. M. Ward, Queen Mary's Sidcup NHS Trust; Dr R. Gale, Dr V. Ratnayake, and Dr D. G. Wells, William Harvey Hospital; Dr M. Aldouri and Dr V. E. Andrews, Medway Maritime Hospital; Dr A. Stark, Dumfries \& Galloway Royal Infirmary; Dr A. D. J. Birch, Falkirk District Royal Infirmary; Dr R. Chopra, Prof I. M. Franklin, Dr G. McQuaker, and Dr A. N. Parker, Glasgow Royal Infirmary; Dr J. D. Browning, Wishaw General Hospital; Dr R. C. Tait, Southern General Hospital; Dr R. B. Hogg, Stobhill NHS Trust; Dr R. A. Sharp and Dr P. J. Tansey, Victoria Infirmary; Dr E. J. Fitzsimons, Dr N. P. Lucie, and Dr R. Soutar, Western Infirmary; Dr E. Chalmers, Dr D. J. Culligan, Dr A. A. Dawson, and Dr J. Tighe, Aberdeen Royal Infirmary; Dr J. Tucker, Borders General Hospital; Dr E. J. Fitzsimons, Dr J. A. Murphy, Dr A. Raafat, and Dr W. Watson, Monklands District General; Dr D. T. Bowen, Dr P. Cachia, Dr K. Gelly, Dr A. Heppleston, and Prof M. J. Pippard, Dundee Teaching Hospitals NHS Trust; Dr C. J. Lush, Raigmore Hospital; Dr A. C. Parker, Royal Infirmary of
Edinburgh; Dr S. Y. Rogers, Victoria Hospital; Dr J. M. Davies, Dr P. Ganly, Dr P. R. E. Johnson, Dr M. J. Mackie, and Dr P. H. Roddie, Western General Hospital; Dr D. R. Edwards, Dr M. Goodrick, Dr D. I. Gozzard, and Dr C. Hoyle, Glan Clwyd Hospital; Prof A. K. Burnett, Dr S. H. Lim, Dr C. Poynton, Dr C. Rowntree, and Dr J. A. Whittaker, University Hospital of Wales; Dr D. H. Parry and Dr J. R. C. Seale, Ysbyty Gwynedd; and Dr R. J. G. Cuthbert, Dr Z. R. Desai, Dr F. G. C. Jones, Dr M. F. McMullin, and Dr T. C. M. Morris, Belfast City Hospital.

Republic of Ireland. Dr J. R. O'Donnell, Beaumont Hospital; Prof E. L. Egan and Dr M. Murray, University College Hospital, Dublin; Dr D. McCarthy, St. Vincent's Hospital; Dr P. V. Browne and Prof S. R. McCann, St. James Hospital; and Dr H. Enright, Adelaide/Meath Hospitals.

New Zealand. Dr P. Ganly and Dr W. N. Patton, Canterbury Health Laboratories; Dr S. Gibbons, Prof D. N. J. Hart, Dr D. Heaton, and Dr R. L. Spearing, Christchurch Hospital; Dr C. H. Beresford and Dr C. Newhook, Dunedin Hospital; Dr B. Baker and Dr P. Harper, Palmerston North Hospital; Dr G. Corbett, Dr S. May, and Dr H. Pullon, Waikato Hospital; and Dr J. C. Carter, Dr J. Phillips, and Dr K. R. Romeril, Wellington Hospital.

Italy. Prof A. M. Carella, Azienda Ospedale San Martino; Dr M. Crugnola and Prof V. Rizzoli, Università degli Studi Di Parma; Prof U. Marini, Ospedale S. Carlo Borromeo; Dr DeCataldo and Dr Nosari, Ospedale Niguarda; and Dr A. Donelli, Servizio Di Ematologia, Modeno.

\section{ECOG 2993 doctors}

Dr J. A. Sparano, Albert Einstein College (NY); Dr M. B. Atkins, Beth Israel Deaconess Medical Center; Dr J. Aisner, Cancer Institute of New Jersey; Dr B. J. Averbook, Case Western-MetroHealth Medical Center; Dr J. L. Wade III, Central Illinois CCOP (EAPP); Dr S. S. Grubbs, Christiana Care CCOP (EAPP); Dr E. R. Pajon Jr, Colorado Cancer Research Program CCOP; Dr J. P. Kuebler, Columbus CCOP (EAPP); Dr W. C. Wood, Emory University; Dr G. Y. Locker, Evanston Hosp. (CCOP); Dr L. J. Goldstein, Fox Chase Cancer Center; Dr P. J. Loehrer Sr, Indiana Univ Medical Center; Dr C. S. Vallejos, Instituto de Enfermedades Neoplasicas; Dr H. M. Lazarus, Ireland Cancer Center, University Hospitals of Cleveland; Dr A. A. Forastiere, Johns Hopkins University; Dr J. Gilbert, LSU Medical Center CCOP; Dr T. K. Banerjee, Marshfield Clinic; Dr T. M. Habermann, Mayo Clinic; Dr P. Flynn, Metro-Minnesota CCOP: Abbott-NW; Dr J. A. Kish, Moffitt Cancer Center; Dr H. Hochster, New York University Medical Center; Dr R. H. Ansari, Northern Indiana CRC CCOP; Dr A. B. Benson III, Northwestern University; Dr C. G. Kardinal, Ochsner Clinic; Dr P. Wiernik, Our Lady of Mercy Cancer Center; Dr W. B. Rybka, Penn State Cancer Institute; Dr D. G. Haller, University of Pennsylvania; Dr J. M. Kirkwood, University of Pittsburgh; Dr J. M. Lombard, University of Pretoria; Dr L. Baez, San Juan Minority Based; Dr L. Wong, Scott \& White CCOP; Dr J. A. Ellerton, Southern NV Cancer Research Foundation; Dr G. K. Bayer, St Vincent Hospital Regional Cancer Center; Dr H. Pinto, Stanford University; Dr J. K. Erban, Tufts/New England Medical Center; Dr F.-C. Lee, University of New Mexico; Dr D. H. Johnson, Vanderbilt University; Dr P. S. Ritch, Medical College of Wisconsin; and Dr J. A. Stewart, University of Wisconsin.

\section{References}

1. Farber S, Diamond LK, Mercer RD, et al. Temporary remissions in acute leukemia in children produced by folic acid antagonist, 4-aminopteroylglutamic acid (aminopterin). N Engl J Med. 1948; 238:787-792.

2. Schrappe M, Reiter A, Ludwig WD, et al. Improved outcome in childhood acute lymphoblastic leukemia despite reduced use of anthracyclines and cranial radiotherapy: results of trial ALLBFM90. German-Austrian-Swiss ALL-BFM Study Group. Blood. 2000;95:3310-3322.

3. Silverman LB, Gelber RD, Dalton VK, et al. Approved outcome for children with acute lymphoblastic leukemia: results of Dana Farber Consortium protocol 91-01. Blood. 2001;97:1211-1218.

4. Schauer P, Arlin ZA, Mertelsmann R, et al. Treat- ment of acute lymphoblastic leukemia in adults: results of the $\mathrm{L}-10$ and $\mathrm{L}-10 \mathrm{M}$ protocols. J Clin Oncol. 1983;1:462-470.

5. Hoelzer D, Thiel E, Loffler H, et al. Prognostic factors in a multicenter study for treatment of acute Iymphoblastic leukemia in adults. Blood. 1988;71: 123-131.

6. Larson RA, Dodge RK, Burns CP, et al. A fivedrug remission induction regimen with intensive consolidation for adults with acute lymphoblastic leukemia: cancer and leukemia group B study 8811. Blood. 1995;85:2025-2037.

7. Taylor PR, Reid MM, Bown N, et al. Acute lymphoblastic leukemia in patients aged 60 years and over: a population-based study of incidence and outcome. Blood. 1992;80:1813-1817.
8. Chessells JM, Hall E, Prentice HG, et al. The impact of age on outcome in lymphoblastic leukaemia; MRC UKALL X and XA compared: a report from the MRC Paediatric and Adult Working Parties. Leukemia. 1998;12:463-473.

9. Gokbuget N, Hoelzer D, Arnold R, et al. Treatment of adult ALL according to protocols of the German Multicenter Study Group for Adult ALL (GMALL). Hematol Oncol Clin North Am. 2000; 14:1307-1325.

10. Kantarjian HM, O'Brien S, Smith TL, et al. Results of treatment with hyper-CVAD, a dose-intensive regimen, in adult acute lymphocytic leukemia. J Clin Oncol. 2000;18:547-561.

11. Petersdorf SH, Kopecky KJ, Head DR, et al. Comparison of the L10M consolidation regimen 
From www.bloodjournal.org at UCL Library Services on September 15, 2008. For personal use only.

to an alternative regimen including escalating methotrexate/L-asparaginase for adult acute lymphoblastic leukemia: a Southwest Oncology Group Study. Leukemia. 2001;15:208-216.

12. Annino L, Vegna ML, Camera A, et al. Treatment of adult acute lymphoblastic leukemia (ALL): long-term follow-up of the GIMEMA ALL 0288 randomized study. Blood. 2002;99:863-871.

13. Linker C, Damon L, Ries C, Navarro W. Intensified and shortened cyclical chemotherapy for adult acute lymphoblastic leukemia. J Clin Oncol. 2002;20:2464-2471.

14. Hunault M, Harousseau JL, Delain M, et al. Better outcome of adult acute lymphoblastic leukemia after early genoidentical allogeneic bone marrow transplantation (BMT) than after late high-dose therapy and autologous BMT: a GOELAMS trial. Blood. 2004;104:3028-3037.

15. Thomas X, Boiron JM, Huguet F, et al. Outcome of treatment in adults with acute lymphoblastic leukemia: analysis of the LALA-94 trial. J Clin Oncol. 2004;22:4075-4086.

16. Miller DR, Coccia PF, Bleyer WA, et al. Early response to induction therapy is a predictor of disease-free survival and late recurrence of child acute lymphoblastic leukemia: a report of Children's Cancer Study Group. J Clin Oncol. 1989;7: 1807-1815.

17. Laughton SJ, Ashton LJ, Kwan E, et al. Early responses to chemotherapy of normal and malignant hematologic cells are prognostic in children with acute lymphoblastic leukemia. J Clin Oncol. 2005;23:2264-2271.

18. Wetzler M, Dodge RK, Mrozek K, et al. Prospective karyotype analysis in adult acute lymphoblas tic leukemia: the cancer and leukemia Group B experience. Blood. 1999;93:3983-3993.

19. Cytogenetic abnormalities in adult acute lympoblastic leukemia: correlations with hematologic findings outcome: a Collaborative Study of the Group Francais de Cytogenetique Hematologique. Blood. 1996;87:3135-3142.

20. Maurer J, Janssen JW, Thiel E, et al. Detection of chimeric BCR-ABL genes in acute lymphoblastic leukaemia by the polymerase chain reaction. Lancet. 1991;337:1055-1058.

21. Westbrook CA, Hooberman AL, Spino C, et al. Clinical significance of the BCR-ABL fusion gene in adult acute lymphoblastic leukemia: a Cancer and Leukemia Group B Study (8762). Blood. 1992;80:2983-2990.

22. Gleissner B, Gokbuget N, Bartram CR, et al. Leading prognostic relevance of the BCR-ABL translocation in adult acute B-lineage lymphoblastic leukemia: a prospective study of the German Multicenter Trial Group and confirmed polymerase chain reaction analysis. Blood. 2002;99: 1536-1543.

23. Copelan EA, McGuire EA. The biology and treatment of acute lymphoblastic leukemia in adults. Blood. 1995:5:1151-1168.

24. Hoelzer DF. Diagnosis and treatment of adult acute lymphoblastic leukemia. In: Wiernik PH, Canellos GP, Dutcher JP, Kyle RA, eds. Neoblastic Diseases of the Blood. 3rd ed. New York, NY: Churchill Livingstone; 1996:295-316

25. Laport GF, Larson RA. Treatment of adult acute lymphoblastic leukemia. Semin Oncol. 1997;24: 70-82.

26. Foon KA, Todd RF. Immunologic classification of leukemia and lymphoma. Blood. 1986;68:1-31.

27. Boucheix C, David B, Sebban C, et al. Immunophenotype of adult acute lymphoblastic leukemia, clinical parameters, and outcome: an analysis of a prospective trial including 562 tested patients (LALA87): French Group on Therapy for Adult Acute Lymphoblastic Leukemia. Blood. 1994;84: 1603-1612.

28. Baumer JH, Mott MG, Gentle TA. Sex and prognosis in childhood acute lymphoblastic leukaemia [letter]. Lancet. 1978;2:673.

29. Hammond D, Sather H, Nesbit M, et al. Analysis of prognostic factors in acute lymphoblastic leukemia. Med Pediatr Oncol. 1986;14:124-134.

30. Chessells JM, Richards SM, Bailey CC, et al Gender and treatment outcome in childhood lymphoblastic leukaemia: report from the MRC UKALL trials. Br J Haematol. 1995;89:364-372.

31. Shuster JJ, Wacker P, Pullen J, et al. Prognostic significance of sex in childhood B-precursor acute lymphoblastic leukemia: a Pediatric Oncology Group Study. J Clin Oncol. 1998;16:2854-2863.

32. Pui CH, Boyett JM, Relling MV, et al. Sex differences in prognosis for children with acute lymphoblastic leukemia. J Clin Oncol. 1999;17:818824
33. Kaplan EL, Meier P. Non-parametric estimation from incomplete observations. J Am Stat Assn. 1958:53:457-481.

34. Goldstone AH, Chopra R, Buck G, et al. The outcome of 267 Philadelphia-positive adults in the International UKALL XII/ ECOG E2993 study: final analysis and the role of allogeneic transplant in those under 50 years [abstract]. Blood. 2003; 104:268a.

35. Gaynor J, Chapman D, Little C, et al. A causespecific hazard rate analysis of prognostic factors among 199 adults with acute lymphoblastic leukemia: the Memorial Hospital experience since 1969. J Clin Oncol. 1988;6:1014-1030.

36. Lamanna N, Weiss M. Treatment options for newly diagnosed patients with adult acute lymphoblastic leukemia. Curr Hematol Rep. 2004;3: 40-46.

37. Cataland SR, Daugherty CK, Weseman EC, Larson RA. Preliminary experience with a new chemotherapy regimen for adults with acute lymphoblastic leukemia. Leuk Lymphoma. 2001;41:297307.

38. Weiss MA, Heffner, Lamanna N, et al. A randomized trial of cytarabine and high-dose mitoxantrone compared to a standard vincristine-prednisone-based regimen as induction therapy for adult patients with ALL [abstract]. Proc Am Soc Clin Oncol. 2005;23:574s.

39. Mortuza FY, Papaioannou M, Moreira IM, et al. Minimal residual disease tests provide an independent predictor of clinical outcome in adult acute lymphoblastic leukemia. J Clin Oncol. 2002;20:1094-1104.

40. Boissel N, Auclerc MF, Lheritier V, et al. Should adolescents with acute lymphoblastic leukemia be treated as old children or young adults? Comparison of the French FRALLE-93 and LALA-94 trials. J Clin Oncol. 2003;21:774-780.

41. Schiffer CA. Differences in outcome in adolescents with acute lymphoblastic leukemia: a consequence of better regimens? better doctors? both? J Clin Oncol. 2003;21:760-761.

42. Herold R, von Stackelberg A, Hartmann R, et al. Acute lymphoblastic leukemia-relapse study of the Berlin-Frankfurt-Munster Group (ALL-REZ BFM) experience: early treatment intensity makes the difference. J Clin Oncol. 2004;22:569570 . 